This is an Accepted Manuscript of an article published by Taylor \& Francis in Feminist Media Studies on 31 October 2015, available online: http://www.tandfonline.com/doi/full/10.1080/14680777.2015.1093145

Or http://www.tandfonline.com/eprint/aC9luthNZKcUIJEiviPW/full

\title{
Performing the "Quing of Berlin": Transnational Digital Interfaces in Queer Feminist Protest Culture
}

\section{Emily Spiers}

Abstract: This paper employs the figure of the "interface" to explore the work of German feminist rapper and spoken-word performer Sookee (Nora Hantzsch), who constitutes an ideal case-study for examining the interface between digital technologies, transnational feminisms and local activism. Sookee is an underground hip-hop artist and queer political activist in Berlin, a location which features in her work as a site of subcultural dissent and contested identities. Sookee is also an academic; a youth outreach worker; a significant online presence and an international creative collaborator. As such, she navigates the interfaces between multiple social groups, media, discourses and cultural contexts — regional, national and transnational. This article focuses on the digital circulations of Sookee's material against the backdrop of her local performative and activist work. Her transnational collaborations with women MCs and poets from South Africa and America, as well as Europe, celebrate cultural, linguistic, racial and ethnic difference by bringing in a diverse range of feminist voices to the German context.

Keywords: German hip-hop, digital circulation, spoken-word poetry, queer feminism, performance 
This article focuses on the digital circulations of material produced by the queer feminist rapper and spokenword performer Sookee against the backdrop of her local performative and activist work. When investigating Sookee's online presence, I refrain from conceptualizing the virtual world as a type of “cyberutopia" (Paterson 1998; van Zoonen 2002), drawing instead on a model of queer cyberfeminism that surpasses the binaries of mind/online (agency) versus corporeality/offline (cultural determination). With recourse to Butler, Grosz and Barad's thinking on performativity, corporeality and "agential intra-activity" (Barad 2003), I will demonstrate that Sookee's raps as well as the accompanying videos and spoken-word poems celebrate language's political potency — its capacity to provoke critical thought and challenge normative socially constructed assumptions relating to gender, sexuality and race, in particular. At the same time Sookee's work and the comments she makes on her website, on Facebook and Twitter make reference to the importance of considering the materiality of the embedded and embodied subject, an emphasis which reveals the artist's reluctance to over-rely on the discursive paradigm alone to enact her critique. Elements of queer theory combined with the deployment of politicized language in Sookee's work find their expression in the performative material body of the artist herself — in her voice and appearance, the choreographed dance routines and the range of gestures she uses — and the "polysensual" layering of music, poetic language and audio-visual material (Gräbner 2011). Her oeuvre demonstrates the artist's unrelenting insistence on the importance of considering the relationship between discourse, language and material bodies: how discourse and language produce embodied subjects, but also how bodies may actively reconfigure discursive norms. Sookee's focus on the relationship between discourse and material bodies generates an at times ambivalent attitude on the part of the performer towards the increasingly medialized context in which she works. This ambivalence reveals itself in her comments about the drawbacks of online culture, which align uneasily with her reliance on that same culture in her professional life.

\section{Queer Berlin, German Feminisms, and Global Hip-Hop}

Sookee (given name Nora Hantzsch), self-proclaimed “quing of berlin”, has been active on Berlin's hip-hop scene since the early 2000s and the spoken-word scene since 2006. The moniker "quing" is an 
ambiguous term which, on the one hand, can be read as a gendered hybrid of "queen" and "king" and, on the other, as "qu-eering" the word king. Sookee has lately become the object of mainstream media attention, due in part to her participation in recent high-profile feminist and anti-homophobia campaigns. One Billion Rising, the global campaign to end violence against women (initiated by American writer Eve Ensler), gained Sookee's support in the form of her song of the same name (2013) and she was active in the transnational SlutWalk campaign as it took hold in Germany in 2011. Her song "Pro Homo", which was released in the same year, responds to what the performer views as hip-hop's endemic homophobia, not only in Germany, but globally. ${ }^{\mathrm{i}}$ Her intervention resonates with wider concerns in Germany relating to hip-hop's politics - the misogyny and violence promoted by many of its practitioners, in particular. ${ }^{\text {ii }}$

Much research has already been done into the global transferences and local adaptations of US popular culture and, in particular, hip-hop and rap. Agnes C. Mueller, for example, eschews the term "Americanization", preferring the notion of cultural "hybridization" in relation to Germany (Mueller 2004, 5-6). Mueller argues that cultural transfers are not passive but active processes, in which cultures re-appropriate and fashion material to suit local purposes. She contends that American popular culture, for example, often provides Germany's minority communities with a medium to articulate racial, ethnic and economic difference from mainstream German culture. Local identity, in some cases, can even be strengthened as a result of globalizing discourses and the "struggle over the values of social or cultural experiences" that often ensues. Writing about the "languages" of "global" hip-hop, Marina Terkourafi observes that artists in diverse cultural contexts draw on hip-hop in order to offer incisive critiques of dominant domestic cultures and to engage with local issues of ethnicity and power, employing their connection with what is conventionally understood as an African-American genre to explore local experiences of marginality $(2010,3)$. Terkourafi's observations certainly resonate with elements of the German hip-hop scene; two of its prominent figures, Bushido and Sido, are of hybrid ethnic descent: Bushido's mother was German and his father Tunisian, whereas Sido's father was German and his mother Sinti. As Anikó Imre has argued in relation to the European context, however, a phenomenon resulting 
frequently from such adaptations is that the "marginal" or "minority" hip-hop artist then "automatically stands in for the entire disenfranchised community, whose hierarchical sexist and heteronormative structure is left intact or even reinforced through the appeal to [...] authenticity. [...] What appears to maintain the authenticity of transnational hip hop is precisely the hyperbolic performance of racialized, heterosexual manhood" (Imre 2009, 113). In the context of Imre's observations, Sookee's work challenges the representational claims of artists like Bushido and Sido and opens up space for alternative "marginal" or "minority" voices — specifically queer, female, and left-wing ones — within the German hip-hop scene. As a result, Sookee deconstructs the notion of "authenticity" attending performances of racialized, heterosexual manhood in the work of artists like Sido and Bushido, highlighting the importance of viewing gender and sexuality as social constructs.

Despite her awareness of the gendered, racialized dynamics of global and locally produced hiphop, Sookee claims on her own website that she is "happy to be an activist in this scene [hip-hop] because it offers a broad spectrum of performative and communicative opportunities." The digital circulations of her work also allow Sookee to establish an independent performative and communicative platform outside the male-dominated mainstream rap and hip-hop scene in Germany and in direct opposition to the “macho posing” [mackerige Gepose] of some of that scene's most well-known protagonists, including Bushido and Sido. Sookee's use of the term "activist" here gestures towards her understanding of creative work as an extension of her left-wing feminist activism. Sookee does not therefore condemn hip-hop per se. Instead, she works as part of a hip-hop collective, called ticktickboom, which provides a creative and political "home" for artists from Berlin, Bremen, Hamburg and Nürnberg. According to their website, the collective is home for over twenty "Sänger*innen, DJ*anes, Beatproduzent*innen, Veranstalter*innen, Grafiker*innen und Rapper*innen, die linken Hip Hop machen und feiern” [singers, dj*anes, beat producers, organisers, graphic artists and rappers, who produce left-wing hip-hop and party]. The use of the asterisk here is a political-linguistic tool for adapting the gendered German language. The asterisk links the masculine and feminine plural endings, making it clear that both genders are included, rather 
than using either both masculine and feminine plurals or the "universal" masculine. This strategy resembles the employment of the capital I (in German "Binnen-I" [internal I] feminist linguists began using in the 1970s and 1980s.

The hip-hop collective describe their left-wing hip-hop as "Zeckenrap". The word "Zecke" constitutes a direct (mis-)translation of the English "tick" from the collective's name and connotes an ironic re-appropriation of a term of insult for politically conscious rap. The reference to a hidden parasite arguably also gestures (somewhat ironically) towards their strategy of subversion within German hip-hop culture:

We've had enough of the macho posing going on in a large part of the "hip-hop scene" along with the homophobic and sexist language. But we don't want anything to do with the hypocrisy politicians and the media show when it comes to hip-hop either. Instead we choose our own focal points and work to establish commonalities and alliances. We're at home in the subculture of the left and want to contribute to the soundtrack of the movement. We thrive on exchange. We hate apathy. (Ticktickboom website 2015) ${ }^{\mathrm{iii}}$

Ticktickboom, and Sookee herself, draw on the political traditions of US hip-hop and rap, setting them apart from the popular adaptations of hip-hop in Germany which produced pop-rap and the kinds of commercial rap that uses "sexist, violent, and in some cases nationalist imagery" (Stehle 2011, 1). Sookee and her collective employ political rap as a "foil through which issues like marginalization and racism [can] be thematized" (Stehle 2011, 4).

In contrast, too, with social and political narratives that over the last three decades have emphasized the importance of integration in generating a harmoniously "multicultural" Germany, Sookee and ticktickboom focus on "claiming space, voice, and agency; on difference; and on creating a counterdiscourse to neo-Nazi, neoconservative, and nationalistic politics" (Stehle 2011,4). As the above quotation from ticktickboom's website demonstrates, the collective also sets itself apart from media and 
government voices whose censure of hip-hop culture and rap in Germany, construed as the creative product of the urban ethnic "ghetto", can function to veil neoconservative nationalistic ideologies.

Sookee lives in Neukölln, an ethnically diverse borough of Berlin that has been the locus of growing tensions in the past few years as a result of exclusionary local authority initiatives that disadvantage poorer, often migrant, members of the community (or the "Block/Kiez" [block/neighbourhood], as a recent antiexclusion initiave put it). ${ }^{\text {iv }}$ Neukölln forms a prominent backdrop for Sookee's video for the rap “Zusammenhänge/Spuck auf rechts \#12” [Connections/Spit on the right wing] (2013). This anti-fascist piece focuses on the ideological commonalties shared by the far-right, neo-Nazi groups and the "bürgerliche Mitte" [bourgeois centre], and the video stages the act of reclaiming the streets of Neukölln, whose locational specifity is made clear by frequent shots of underground maps at stops in that area. Sookee and her collaborator Spezial K. rap outside, on the streets and in a park, while cut-away shots feature close-ups of disembodied hands placing anti-fascist, left-wing and queer-feminist stickers over those already placed in Neukölln by neo-nazi and far-right, anti-immigration activists. This palimpsest of politicized urban space becomes a visualization of the rap's lyrics, which claim to begin “den Kampf mit Sprache, Punches, Parties, Straßenblockaden" [the fight through language, punches, parties, street blockades].

Sookee's reference to the performative potential of hip-hop above also hints at her immersion in the language of queer feminist theory. The political weapon she professes to utilize in her creative production is "subversion" ("purpleize hiphop" 2011) and this strategy for combatting the regressive elements in hip-hop comprises what Linda Hutcheon might call a "challenge from within" (1998). However, Sookee still maintains an emphasis on the affective potency of hip-hop - especially when it becomes a vehicle for queer feminist critique. In her song "purpleize hiphop” from 2011, for example, the colour purple becomes synonymous with a tradition of Western feminist activism the artist feels is commensurate with queer hiphop culture in Germany: “finally queers can celebrate hip-hop again / and it's clearly because my hits are purple." Through her symbolic use of the colour purple, Sookee builds a bridge between previous feminist generations and her own queer feminism, which is fiercely intersectional and highly influenced by Anglo- 
American third-wave discourse. Having graduated in linguistics and gender studies, Sookee's feminist politics dismantle identity categories that configure gender, sexuality, race, nationality and class as hierarchical and fixed. This approach, combined with her left-wing anti-capitalist stance, distances her from both Alice Schwarzer's equality feminism [Gleichheitsfeminismus] and the post-2000 crop of neoliberal individualists, or "New German Girls.",

Despite the visual marker of feminist continuity in the form of the colour purple, the distance between Sookee's feminism and that of Germany's long-standing public feminist figurehead Alice Schwarzer became apparent in a 2008 podium discussion in Berlin called "HipHop-Girlz meet Alice Schwarzer". Taking into account the subjective mediation of mainstream news reporting, the event appears to have revealed a schism between the representatives on the podium. As the Spiegel journalist reports: MC Sookee wants nothing to do with feminism à la Schwarzer. She complains about being booked on the "women-question" ticket. She wants to move past the "category of gender" and talk about homophobia and racism in rap. In other words, "third-wave feminism" — rather than the eternal gender question "sibling solidarity instead of sisterhood". The audience applauds; that sounds good and new. ${ }^{\mathrm{vi}}$ (Wild, 2008)

While Schwarzer suggests that the two MCs on the stage — Sookee and MC Pyranja, founder of the women's rap group Ostblokk and important role model for Sookee — adopt a strategy of hyperbolic mimicry as a method of countering the machismo of male commercial rappers in Germany, the two rappers appear more interested in dismantling gender categories, queering, rather than inverting them.

The German rapper and academic Reyhan Şahin (a.k.a Lady Bitch Ray) was also invited to this podium discussion but did not in fact attend. Sookee and LBR (Lady Bitch Ray) have their academic backgrounds in common, and they share an interest in linguistics, power and gender, in particular, as well as an immersion in German hip-hop. Other elements, however, distinguish them from one another culturally, politically and artistically. LBR has discussed the important role her ethnicity plays in her work; of TurkishGerman descent, LBR in many ways personifies the kinds of tensions emerging from broader cultural 
encounters with hybrid ethnic identities in Germany, in LBR's case especially those arising around the issue of female sexuality within Turkish-German culture. Sookee, on the other hand, was born to parents who escaped former East Germany as political exiles, an experience that may have influenced the political trajectory of her work, as well as her predilection for probing layers of meaning and deconstructing language. Sookee's anti-capitalist stance and played-down style also contrast with LBR's aesthetics of excess and consumer fetishism. In her battle-rap style LBR presents an artistic and political challenge to male-dominated culture through a performative parody of the hypersexualized heteronormative female (Stehle 2012), whereas this is a stereotype Sookee seeks to dismantle in her work.

In terms of recent trends in mainstream popular feminism, discussed in the introduction to this issue, Sookee's stance appears supportive but distant. This is presumably due to her staunch anti-capitalism and radical approach to intersectional feminist politics — especially in relation to race and sexuality —, which arguably contrasts with that practiced by the recent crop of popfeminist Alpha Girls. ${ }^{\text {vii }}$ She has been, however, featured in recent issues of the self-proclaimed popfeminist publication Missy Magazine (in 2012, 2013 and 2015) and on the online feminist forum Mädchenmannschaft [Team Girl] (in 2010, 2011 and 2012) but does not embed links to these or any other feminist media on her website. She does, however, follow a variety of German-language and Anglophone feminist platforms on the more fluid Twitter, from $\underline{\text { Missy Magazine and its editors Stefanie Lohaus and Chris Köver, to US feminist magazines/websites Bitch, }}$ Bust, Feministing and multiple LGBTQ and anti-fascist Twitter feeds. In a 2013 statement published in Missy Magazine, Sookee describes her approach to recent feminist debates:

My task is more about creating communicative bridges and being visible. So I concern myself with queer-feminist activism in between male-dominated subcultures and within autonomous antifascist/left-wing party political contexts. On the one hand I try to support the larger alliances driven by liberal women* and, on the other, to follow closely the debates led by radical-feminist activists. $^{\text {viii }}$ (Sookee 2013) 
Sookee's inclusive and collaborative stance, exemplified by the image of a "communicative bridge", suggests that her approach is one of supporting multi-vocal feminist platforms. This strategy is echoed by the multi-level nature of her creative and political work, which, as I will show, occurs in multiple contexts and circulates via multiple media channels.

As an authorial and performative figure, Sookee constitutes an ideal case-study for examining the interface between digital technologies, transnational feminisms and local activism. As well as performing queer political activism on Berlin's underground hip-hop circuit — "queering" German hip-hop, so to speak - she also produces work which celebrates "queer" identity in an urban location that features in her work as a site of contested identities. Sookee has furthermore immersed herself in the academic study of gender theory, engages in youth outreach work all over Germany, and has undertaken international creative and feminist collaborations with female hip-hop artists, from amongst other places, the US, Britain, the Democratic Republic of Congo, and South Africa. ${ }^{\mathrm{ix}}$ Most importantly, her online presence, in the form of her website, Twitter feed, Facebook site and YouTube channel, functions as a hub - a virtual interface - connecting the multiple elements of her social, political and creative engagement in the public sphere with a single, unified and visually powerful "brand": the artist herself. By means of this digital interface, Sookee qua authorial/performative/critical figure is able to consolidate the nexus of social groups, discursive and cultural contexts — regional, national and transnational — she targets with her queer-feminist critique.

\section{Digital Interfaces}

Postcolonial and feminist scholars of the digital world have drawn on the work of Homi Bhabha, Michel Foucault and Henri Lefebvre in order to foreground the spatial in cyberspace (Davis 2010), theorizing the web as an "in-between space", a paradigm of cultural hybridity (Bhabha 1994), or as a "heterotopia" - a real place containing many other imaginary, historically or geographically distant, even utopian places (Foucault 1984). While Foucault does not suggest that heterotopias constitute advantageous spaces from which to articulate critique, his work on heterotopias has been drawn on by some cyberfeminists 
in a similar way to Bhabha's "in-between spaces": to signify a liminal space of resistance to dominant cultural and political paradigms (Davis 2010). My use of the term "cyberfeminist" here historicizes these debates, situating them within the technological turn of the early 1990s that is exemplified by the work of, amongst others, Rosi Braidotti, Sadie Plant, and Donna Haraway, whose "cyborg” was deemed by Squires and Kemp in 1997 to constitute "the icon of contemporary feminism" (470).

Conceptualizations of the digital world as a space of unfettered feminist resistance have --historically --- produced understandings of cyberfeminist agency as an effect of entering virtual space in a disembodied state. The online "space" inhabited by the disembodied user has been construed, for example, as a "playground for experimenting with gender symbols and identity, a space to escape from the dichotomy of gender and the boundaries produced by physical bodies" (van Zoonen 2002, 12). In models like these, the web becomes construed as an exclusively discursive realm where the user may at last realize full autonomy through achieving a disembodied state. The female body — indeed the entire material world — is portrayed as hopelessly determined, while the mind and the discursive paradigm it accesses enjoy unencumbered and autonomous performative opportunities. I employ the term "performative" here to gesture towards an understanding of performativity, favoured by some social constructionists, which is at odds with the sense in which it becomes used by thinkers like Judith Butler and Karen Barad, for example. Barad summarizes this conceptual divergence in the following manner:

Performativity, properly construed, is not an invitation to turn everything (including material bodies) into words; on the contrary, performativity is precisely a contestation of the excessive power granted to language to determine what is real. Hence, in ironic contrast to the misconception that would equate performativity with a form of linguistic monism that takes language to be the stuff of reality, performativity is actually a contestation of the unexamined habits of mind that grant language and other forms of representation more power in determining our ontologies than they deserve. (Barad 2003, 802) 
In other words, performativity in fact highlights the role of the material body in exploring the question of ontology rather than displacing the body through excessive focus on language and representation. Understandings of performativity that remain entrenched within the linguistic paradigm — as well as some of the earliest cyberfeminist conceptualizations of the digital world — often rely upon a Cartesian model of mind/body dualism that prioritizes mind over body and posits cyberspace as a "utopian replacement for the spaces of lived experience" [original emphasis] (Brophy 2010, 932). As Brophy and Boler point out, models like these fail to take into consideration that fact that the existence of an ambiguous digital world does not in itself guarantee the subversion or deconstruction of normative identities. These may after all be mimetically reproduced and reinforced rather than replaced. Furthermore, the association of agency with cyberspace implies a move to abandon the lived material of bodies to their culturally determined fate and deal only with discursive representations of bodies online. Such critiques of early cyberfeminism, its utopian tendencies and binary thinking, have been influential in the move to linguistically reframe the field through using the pluralized term "digital feminisms" rather than "cyberfeminism".

Sookee herself has been accused of perpetuating binary models — in terms of her thinking about gender but also in relation to the question of body/mind dualism discussed here. Her most introspective raps and poems, for example, often reflect critically upon her previous work, revising or at least modifying her political thinking. It is in such pieces that she also engages with the wider reception of her work, often tackling others' interpretations of her ideas in order to accept or refute criticism. In the second of two pieces entitled "Lernprozess", she raps:

Quing's idea was to irritate hip-hop positively / What's queen? What's king? I had nothing to lose / There were people who thought I was referring to two sexes / And constructing a third from them wasn't any better / I understand this objection but don't share it / Because "Quing” looked beyond that right from the start / The line about sexiness disturbed me much more / That I separated head and body and threw out the latter / Who am I to decide that intellectualism / Is more desirable? The insight came really late / Of course it's wrong to demolish identities / Unless 
you're doing it strategically / But it's not me who decides, it's everyone for themselves / I deliver the lines, you read them — both carry weight / I don't want my words to become some kind of benchmark / I'm just starting a discussion about my day-to-day life. ${ }^{\mathrm{x}}$ (Sookee, 2011) This passage is significant for several reasons. It resonates with tension between the speaker's desire to assert interpretative authority over her lines and her acknowledgment of the limits of her authority when it comes to enforcing her intended "meaning." In the first six lines, the speaker reasserts the effect she had intended when using the term "quing", rejecting alternative interpretations that view it as based on unhelpful binary thinking. The critique that she foregrounds language and "intellectuality" over the body, specifically "sexiness", produces a more ambiguous response. She initially appears to accept the idea that she was wrong to demolish "identities" (implicitly those based on hypersexuality) in some of her earliest raps, but adds the caveat that this can be a strategic tool. The implication here is that "quing" was seeking to challenge the idea that only hypersexualized identities are acceptable for some individuals, i.e. women in hip-hop culture, and to explore the possibility of other constructions of self. The accusation that Sookee conceptually prioritizes the mind over the body, intellect over corporeality and theory over lived experience stems perhaps from her generally sophisticated use of language and her tendency to incorporate elements of gender and queer theory into her poems and spoken-word poems.

Scholars like Brophy and Boler draw on the work of feminist theorists like Judith Butler, Elizabeth Grosz and Karen Barad in order to think through the implications for feminist theory and activism of the body/mind dualism in relation to the digital. For Barad, in particular, representationalist claims that the world is divided into two distinct elements: things, on the one hand, and the words which represent them, stem from precisely that Cartesian bifurcation of mind and body that ultimately places mind above body (Barad 2003, 806) and sustains other hierarchized binaries such as nature/culture, man/woman (Grosz 1994, 3). Grosz, on the other hand, draws on an interest she attributes to Butler in the "lived body, the body insofar as it is represented and used in specific ways in particular cultures. [...] [T]he body is neither brute nor passive but is interwoven with and constitutive of systems of meaning, 
signification, and representation" [original emphasis] (Grosz 1994, 18). This is what Butler conceptualizes in her theory of performativity when she argues that "acts, gestures, and desire produce the effect of an internal core or substance, but produce this on the surface of the body [...]. [S]uch acts, gestures, enactments $[\ldots]$ are performative in the sense that the essence or identity that they otherwise purport to express are fabrications manufactured and sustained through corporeal signs and other discursive means" [original emphasis] (Butler 1990, 185).

Performativity, for Butler and Barad, constitutes a process based on repetitive action, a "doing", rather than a static state of being, which generates not only the formation of the subject but also produces the body itself (Barad 2003, 808 [italics mine]). Barad develops Butler's model of performativity in order to develop a model of agency which neither prioritizes discourse over material, nor language over the body, but which combines material and discursive practices in an interdependent and dynamic union. Barad calls this constantly self-adjusting union "agentic inter-activity." She continues:

The world is a dynamic process of intra-activity in the ongoing reconfiguring of locally determinate causal structures with determinate boundaries, properties, meanings, and patterns of marks on bodies. [...] The universe is agential intra-activity in its becoming. The primary ontological units are not "things" but phenomena - dynamic topological reconfigurings/ entanglements/ relationalities/ (re)articulations. And the primary semantic units are not "words" but material-discursive practices through which boundaries are constituted. This dynamism is agency. Agency is not an attribute but the ongoing reconfigurings of the world. (Barad 2003, 8178)

This agency is not, to Barad's mind, the property of humans alone but extends to all matter. The intraagency of the body-computer, for example, produces what Brophy calls the "liminal experience" of being online, a domain which she claims is not dependent upon the mind leaving the body behind (for this, as the previous discussion demonstrates, is now seen as an impossibility), but a material-discursive one, in which bodies and minds interact with other human (and non-human) units of discourse-matter. 
This entails that, for the queer feminist campaigner-performer online, cyberspace cannot only be understood as a "playground for experimenting with gender symbols and identity [away from the] boundaries produced by physical bodies." It also constitutes an arena where the matter involved in creating the technology of virtual space, the question of physical access to the digital world in the first place, the lived body of the user and those represented online, as well as discourses of gender and identity all inform the "doing" of identity by both user and performer. Sookee's performance poems and raps are not just "“words" but material-discursive practices" (Barad 2003) through which boundaries around bodies marked by gender, sexuality, race, and ability become reconfigured.

\section{Body Languages}

Several of Sookee's rap pieces and spoken-word poems conceptualize language as a profoundly material phenomenon, inseparable from the body. In her 2011 collaboration with American rapper Bad Kat, entitled "Wordnerd", Sookee raps about the profoundly physical experience of using language creatively. In the following excerpt, words become produced through movements of the body, fingers become writing implements and syllables take on the properties of oxygen-rich air: "Movement in my hands, gestures, moves, never stop / My fingers are like pens and I write in the air / I suck syllables out of the atmosphere, build meaning out of them / I grapple with the things and they advise me: 'Don't give up!' ${ }^{\text {xi }}$ Words become, metaphorically at least, material objects with which to "construct" meaning and with which the poet-rapper "grapples." Personified words offer encouragement to the writer if she falters, and the finished product emerges not from a dry encounter between the poet's mind and the page but from "somewhere between head, heart and guts" [irgendwo zwischen Kopf, Herz, Leber]. In fact, the speaker equates her brain's language centre with her other erogenous zones, intensifying the sensuality and affective potency of language. By foregrounding the physical aspects of creative composition and performance, the speaker in this piece inserts the question of bodies into language, muddying the distinction between language (as representative of "things") and material (as that which is represented). Language becomes equated intimately with the body rather than as an abstract, disembodied tool. This depiction of language relates in Sookee's 
case predominantly to the spoken word and is thus intimately connected with the sensory experience of vocal performance.

The refrain in "Wordnerd", which is in English although Sookee raps in German and Bad Kat in English, is constructed epistrophically from the repeated word "them", i.e. words, and a list of imperatives suggesting all of the things that can be done to them: "Search them find them chew them spit them / Work them buff them rule them sniff them / Doubt them trust them build them hug them / Ride them sell them kill them love them." The quality of the verbs evokes a sense of words as passive material objects to be found, consumed or sniffed like food, or alternatively, as active, living entities imbued with anthropomorphic qualities prompting intense affective responses like love and hate. Metaphorically, at least, the song portrays language as a tangible entity with concrete qualities. It is interesting to note that, since 2011 , Sookee has had WORD and NERD tattooed on to the knuckles of her left and right hands respectively. This process of puncturing and marking the skin with ink entails that the words quite literally become part of her body.

In Sookee's powerful spoken-word poem "Wortgewaltverherrlichung” [In praise of violent language] from 2010, the speaker criticizes "stories without substance" [Geschichtchen ohne Belang], arguing instead for language to be "granite amazon" [eine granitene Amazone], "shaping papery word husks into tangible / Substantial statements." The virtuosic metaphorical play in this poem reveals a pattern of images which depict language as a material phenomenon which is intimately linked with the speaker's body. At times, the encounter is confrontational, at other times it is erotic: language should "creep" into her pores and make her “sweat golden ideas", "rampage" through her "capillaries." In these images, language becomes an almost disciplinary force, urging the speaker to create and — most importantly — to think critically: “And if I try and shirk, shoot tiny barbed darts of matter / To bore into my thoughts until I understand what I'm thinking about, what I'm / Writing about."xii In the erotic images, language "sheathes" the speaker, "pulsating her to quickness"; it becomes a fertile creative force "impregnating" the speaker with "text babies." Yet the poem ends with the statement that language is both the speaker's "hope" and her "illusion" simultaneously. This conclusion undercuts the metaphorical force of the preceding lines, which has so consistently portrayed 
language as a material phenomenon. Combined with the anaphoric modal construction "Sie soll" [She/it should], which refers to what language should/ is supposed to be or do, this conclusion implies an awareness in the speaker of the degree of wishful thinking involved in her conceptualization of language.

Despite this apparent capitulation to the notion of language as "illusory", i.e. representative and abstract, Sookee's more general understanding of language remains connected with a materialism that is deeply political. In both her creative and youth outreach work, language literally functions as a tool for survival and political change. Sookee works frequently in contexts where the reproducible media --- the videos, the audio-tracks --- she produces require supplementation in terms of her material presence, not only at performance events but especially in pedagogical fora. This point holds political significance as it becomes related to Sookee's self-confessed broader intention, expressed on her website, to transform the ways in which discursively constructed power structures and identities become taken up and redeployed in socially embedded contexts and relations — in particular amongst young people. Through organizations like the Bundeszentrale für politische Bildung [Federal Agency for Civic Education], Gangway e.V., a social-work organization engaging with young people on the streets of Berlin, and cultures interactive e.V., a programme promoting intercultural education and violence prevention in Berlin, Sookee runs workshops on hip-hop, homophobia, sexism and language in schools, community centres and holiday camps. The work she does with these mixed-gender, racially and ethnically diverse groups involves developing the participants' critical media literacy and creative skills. Together they deconstruct rap lyrics and videos, taking apart the representations of violence, gender and sexuality and unpicking the types of language used to talk about women or members of LGBTQ communities. Apart from this critical work, Sookee also incorporates an element of creative writing into her workshops, encouraging participants to develop methods of expressing themselves emotionally and critically through rapping. On her website, Sookee connects this work with what she considers to be the failure of academics and social commentators in the media to engage with lived experiences within the youth cultures they theorize. Viewing academic or journalistic approaches as overly abstract and removed from 
the immediacy and locus of debate, Sookee stresses on her website her intention to initiate dialogue and catalyse change within "present" and not "future society."

For Sookee as an artist, as well as Sookee as a youth worker, writing and performing constitutes a way of working through the effects of traumatic experiences like those described in the pieces "Mach was!" and "bitches butches dykes \& divas." Language enables, for example, the speaker in "Wordnerd" to transform "every wound" [jede Wunde] into a story. One of the artist's central preoccupations is in fact the besieged female and/or queer body in misogynistic heteronormative society. Here, Sookee works towards creating raps and spoken-word poems which are grounded in material concerns, even when removed from the performance context and circulated online.

In the spoken-word poem "Mach was!" [Do something!] from 2011, Sookee explores the moments of sexual harassment experienced by women and members of LGBTQ communities on a daily basis in the public sphere. Her evocative language highlights the degree of physical threat posed by aggressive young men seeking to assert their masculinity at the expense of others:

They rearrange their primary sex organs in an offensively drawn-out fashion, staring nastily at you the whole time, / they stand too close behind you on the underground and breathe you in, / they make comments and intend them to provoke, / they make comments and actually intend them to be compliments, / they can't keep their fingers to themselves. xiii

The sinister, claustrophobic tone of this poem is matched and amplified in the rap "bitches butches dykes \& divas" of the same year, in which the same kind of aggressive young men are portrayed as having “stigmatized us looked at us funny / pilloried us spit at us". Yet the speaker's solution is not to withdraw from the scenes of potential confrontation but to initiate public debate in order to demystify the topic of sexual harassment and to ensure that women and LGBTQ communities claim a visible space in the public arena of the kind Stehle discusses in her work on depictions of city space in German rap productions (Stehle 2011). Sookee's intention is: "To demystify the topic, / To demand public space, make public space". The solution here is founded on the principle of combining discursive change (through debate and discussion) 
and material change (generating and maintaining tangible change by physically occupying space) — each underpinning the other.

The videos accompanying the rap songs "One Billion Rising" (2013) and "D.R.A.G" (2011) seek to enact precisely this kind of material-discursive intervention. Sookee's “One Billion Rising”, the unofficial anthem for the German manifestation of this international movement, was filmed in a Berlin skate hall by German film maker Luci Westphal. The video enacts the claiming of this historically maledominated space by a group of predominantly female hip-hop dancers, BMX bikers, skateboarders and extras. Sookee, who raps in close-up directly to camera for the majority of the piece, is set against a backdrop of dancing, skateboarding and biking women, who mimetically reproduce the song's lyrics by "rising up" to claim and celebrate this safe space of self-expression.

The notion of cyberspace as a material-discursive domain discussed above resonates with accounts of performance poetry — and I would argue rap — which consider this hybrid medium to be "by default located in the moment and the place of the performance" and anchored in the "cultural, social and political position of the poet" (Gräbner and Casas 2011, 14-15). One element omitted here, which the example of Sookee's video to One Billion Rising makes apparent, is the body of the author as a mediator of meaning in the poetry performance. Gräbner and Casas claim that:

The poetry performance almost by default obliges authors to address the question of authorship: the enunciation of the poem by the author him- or herself and the poet's presence at the site of enunciation emphasize the poet's position as an author who accepts responsibility for his or her work. (11)

Yet the claim to interpretive "authority" is not the only effect of the poet's body inserted into the performative space. This is because the practice of occupying physical space in poetry performance and rap performances enables poets to "question through their presence and materiality the cultural, political and national hegemony against which these practices intervene" (Gräbner and Casas, 17). In the case of Sookee's work, her gender, combined with playful modes of self-presentation both on- and offline which incorporate 
the standard attire of hip-hop culture (baseball cap, hooded sweaters, trainers), the pseudonym(s) under which she performs and markers of queer feminist identity (shaven head, tattoos, purple- and/or rainbowcoloured clothing), enact an immediate interrogation of hip-hop's male, homophobic and misogynistic bias. On the one hand, these physical markers made prominent in the performance space (whether on- or offline) “frame [Sookee's] individual authorship within a context of community and collectivity" (Gräbner and Casas, 11). On the other, they frame her within two historically antagonistic communities simultaneously (hip-hop and queer feminist culture), thereby making the artist's body the location of a material-discursive intervention that claims compatibility between two ideologically disparate cultures. At the same time, the author constructs the possibility of a hybrid culture due to the "perlocutionary and illocutionary force" of spoken poetry and raps, which can function to "create community" (Gräbner and Casas, 11).

This strategy can be seen, in particular, in the piece "purpleize hip-hop" mentioned above, in which Sookee invokes — in the present tense — the community she seeks to establish: "not somewhere sometime but here now / purple basie pink triangle rainbow queer rap". xiv In the video accompanying the song D.R.A.G, directed by Laylah Naïmi and Felix Landbeck, the artist pursues a similar strategy by creating a space within the studio used for filming in which Sookee and a heterogeneous group of LGBTQ dancers perform a complex and celebratory dance routine. Rapid editing creates the effect of continuous and instantaneous costume changes for every dancer, the costumes often incorporating an element of crossdressing. Through this motif, the video enacts the spirit of the quote from performer RuPaul which appears on the screen before the video begins: “The saying 'you're born naked and the rest is drag' couldn't be more true.” The tightly choreographed routine creates the impression of a unified body of people moving in unison, evoking a sense of tight-knit community amongst the visually heterogeneous group.

The video to "Pro Homo" employs a similar technique, featuring a group of people dancing to Sookee's music, yet this video incorporates a framing narrative which shows this celebratory scene of queer hip-hop community being filmed and beamed into the homes of unsuspecting citizens through their televisions. The citizens include comically exaggerated representatives of heteronormative society: a senior 
couple, a young woman with a baby, two beer-drinking young men in tracksuits. Their outrage at the intrusion and the content of this song, which challenges homophobia in all areas of society, abates over the course of the video as they are convinced, first, by the musicality of the piece and, second, by Sookee's persuasive arguments.

The performance of poetry or rap thus provides the artist and their audience with the opportunity to probe the contours of identity. The performance itself becomes a meta-poetic comment on the "performative" aspects of identity, probing the moments where the self may become signified differently. As Gräbner and Casas observe:

[T]he performance provides poets with an opportunity to experiment with different, often dissident or marginalized forms of identity. The explicitness of these experiments is the result of a self-reflexive attitude towards authorship and identity promoted by the poetry performance. (11) Reyhan Şahin's alter-ego Lady Bitch Ray provides a cognate example of this type of performative play with identity that rotates around the visual image. As Stehle suggests in relation to LBR, she "self-consciously used imagery of her own body from the very beginning of the 'show' and tried to claim the image and infuse it with her own (female) agency. She used the image as speech-act, which moves the (post-)pornographic performance even closer to just another (postmodern) incarnation of a male pornographic fantasy" (Stehle 2011, 240). In Sookee's case, the use of two pseudonyms (Sookee and Quing) foregrounds the malleability of identity and highlights the possibility of linguistic self-determination. This is a theme she takes up in the spoken-word poem "Rückspiegel" [Rear-View Mirror], for example, in which the speaker considers the act of reading the texts she wrote at some point in the past:

And every few lines you ask yourself: was it really like that? Or have I just misread my experience? / At that moment you are your own historian, which authorizes you to grasp the power of definition for yourself. / You determine the interpretation of your thinking. ${ }^{\mathrm{xv}}$ Here, the process of authoring, then reading, the self-produced text generates a self-reflexive encounter which "authorizes" interpretive authority in the reader rather than the writer. Although they are the same 
person, the strangeness of the self-encounter at one temporal remove implies an inconsistency of selfidentity which gestures towards the fluidity of selfhood over time. However, the second-person singular mode of address (du/you), ostensibly deployed in the manner of a general "one", also conceals within it a direct address to the reader/listener which imbues them with the authority to "determine the interpretation" of their own thinking. This self-reflexive process of reading and writing affords both the speaker and the reader/audience the opportunity to examine the active reconfiguration of self occurring over time: "You can deny your own once-upon-a-time and insist on knowing who you are / or you can decode your own development and follow the path of your / life step by step in order to reflect on who you've become."

The poem was released as an audio track on the album Quing (2010) and has been available as a text on the artist's website since then. These two forms of publication produce remarkably different effects. The audio track features Sookee's voice and is set to evocative music, producing the polysensual layering mentioned above. The enunciation of the poem by Sookee herself binds the work to the authorial figure, her performative persona and brand. Furthermore, the "mediatic hybridity" of the piece, by which I mean the combination of poem, music and sound effects, "accommodates" the fluidity of identity expressed by the poem "within the formalistic aspects of performance" (Gräbner and Casas, 14).

The audio recording of "Rückspiegel" [Rear-View Mirror] and the videos discussed above seek to represent both the immediacy of the performance setting and the political charge of Sookee's appearances at demonstrations like SlutWalk, anti-fascist demonstrations all over Germany or the annual Christopher Street Day events. The primary advantage of the videos is that they continue to circulate online, reaching wide audiences across national boundaries. "Pro Homo", for example, has been viewed 292, 754 times on YouTube, “D.R.A.G.” has had 105, 291 views and “One Billion Rising” has been viewed 188, 182 times.

However, Sookee has been criticized for not including trans* perspectives in her videos for D.R.A.G and Pro Homo. The choreography of D.R.A.G, for example, positions Sookee and another performer who appears to correspond to anatomically male in the front line, and critics have suggested that, even in the moments when they are both dressed up in clothing corresponding to male/female respectively, the 
“identities" on display still run along a binary axis of male/female. This representation of gender performativity and blocking undermines - even subverts - the queer gesture of exploding gender binaries, which Sookee otherwise expressly claims to pursue. In a 2014 interview, Sookee responded to this criticism with reference to the general scrutiny her work is subject to:

As I said, first of all I was celebrated and idealized. Then people noticed that there were limits to the extent to which they could fully celebrate my work. But the thing is, if you have a meal cooked by just one person, then it's clear not everyone's going to like it. If on the other hand lots of people prepare lots of dishes, everyone's going to like the buffet. (Hakan 2014) One interpretation of Sookee's many and varied collaborations with artists from other cultures working in different languages is that this strategy allows her to assemble a "buffet" or, in other words, create contexts in which multiple — often transnational — perspectives may be both expressed and heard in Germany.

\section{Language, Transnational Exchange and the Digital}

The dynamism of the online medium, which affords both local and global reach and supports heterogeneous, ever-developing content, complements one of the themes driving many of Sookee's raps and spoken-word poems: processual change through external and internal critique. Yet, in contrast, her website is strangely static and out-dated. As mentioned earlier, she does not link to other sites, apart from her own Twitter, Youtube and Facebook accounts. There are no pictures of her on the homepage, only at the very bottom of a drop-down menu entitled "Material". Only the colour purple, which dominates the website's formatting, background and font, links it with the author's brand and persona. Her lyrics are abundantly available, but the free-floating texts — especially the spoken-word pieces — reproduced on the website are often short of paratextual information relating them to any time, place or audio-visual publication. The rap lyrics are given some context in terms of the albums they appear on and the year of publication. Yet these 
disembodied texts break the link with the material body and voice of the author and the immediacy of the performative setting.

This is the case generally with Sookee's website, which presents creative works at one remove from the embedded performance space. As such, the website becomes --- predominantly — a decontextualized archive of lyrics. Under the dropdown menu "Songs", the online user is encouraged to follow links from the hyperlinked titles of songs or albums to audio versions of the songs, or in more recent years, to videos of the songs on Sookee's own YouTube channel embedded in the website. Yet there are strangely no links from the actual page providing the lyrics themselves to audio-visual material, which again uncouples text and audiovisual performance. The first dropdown box on the site, "Blog", on the other hand, is used almost exclusively as a functional tool for advertising up-coming events (both Sookee's and other artists' who might potentially be of interest to her fans), concerts or demonstrations in and around Germany. However, this page is updated infrequently and often after the events have taken place. The pages "Suki's hot sauce" and "Information", on the other hand, function as more permanent, static pages, which contain third-person polemical passages concerning the artist's beliefs and political/creative aims. The use of the third-person has a strangely distancing effect, which is increased by the text-heavy, image-light website in general. Likewise, the section "What troubles me" features first-person mini-blogs on gender, nationality and language, but these are not numerous and are infrequently updated.

As a whole, the website functions as a much less dynamic interface than her Twitter and Facebook accounts, which are updated more regularly and through which she interacts with collaborators, friends or followers. Sookee employs them rather than her website to link to other female MCs or feminist, left-wing and creative threads on Twitter. These threads touch on many aspects of her work, creative, political and pedagogical, and they are often linked to various audio, audio-visual and textual sources. In contrast to the website, a medium that demands a certain entrepreneurial gloss and drive to self-promotion that Sookee is perhaps uncomfortable with, her Twitter and Facebook threads are processual, predicated on growth, revision and functionality. 
All three fora reflect a rather striking shift in Sookee's orthographic practices over time, which will have become apparent in the quotations I have included until now. Earlier pieces posted on the website are written with standard German spelling, including conventional capitalization. In the most recent posts from 2014 , however, the artist tends towards consistent use of the lower case and transforms the combination of the letters "-sch" common to the German language to a more anglicized "-sh." These orthographical modifications and Anglicisms represent a deviation from standard German writing practices that is highly political. The decision to forego capitalization symbolically rejects a form of linguistic hierarchization which reflects wider discursive and social hierarchies along the lines of gender, class, sexuality, race and ability. The omission of the letter C in "-sch" constructions combine with Sookee's frequent use of Anglicized terms from Anglophone hip-hop culture and gender theory to denote a preference for linguistic "hybridization" (Mueller 2004, 5-6). This strategy of employing hybrid Anglo-German registers dissent from monoglot German culture - a theme she picks up in a blog on her website entitled "How to Become a German", which examines how identities based on narrow national or linguistic categories are all too often predicated on the "othering" of those from different cultural backgrounds.

Not surprisingly, then, Sookee's own raps demonstrate her response to the "linguistic imperative to keep it real to the genre's Black inner city roots through the adoption of African American English (AAE) linguistic conventions" (Terkourafi 2010,8). As Terkourafi observes, these have gone on to "define a new global Hip Hop Nation Language (HHNL)" (8), which in Sookee's case is also combined with the language and orthographical practices of queer feminist culture, predominantly in the form of noun modification through the use of asterisks to divest words of their linguistic gender specificity (for example, "Rapper*innen").

It is significant, however, that Sookee affords the German language pre-eminence in her creative collaborations with Anglophone artists (she always raps, with the exception of a phrase or two, in German). Her collaborations with American artist Shirlette Ammons, South African rapper Lex Lafoy, Congolese French singer Carmel Zoum and the British rapper Little Simz thus celebrate racial, cultural and linguistic 
difference within a paradigm of creative feminist collaboration across national boundaries. Videos of their collaborations are embedded in Sookee's website, and these artists' Twitter feeds and Facebook pages are all linked through Sookee's, enabling a German-language follower to encounter non-mainstream feminist hiphop, often in other languages. This exchange constitutes a two-way phenomenon, but I consider Sookee's collaborations to be less motivated by the desire for her own artistic persona to circulate in a transnational context and more concerned with making the range of feminist artistic voices within German hip-hop broader and more varied. Sookee's strategy of rapping in German means that when performing and touring with these artists (during “The Purple Velvet Tour” of 2014, for example, which crossed Germany, Austria and Switzerland) she functions as an interface between domestic German-language hip-hop and artists working in different linguistic but similarly politicized contexts. Bringing in a variety of transnational artists working in global hip-hop exposes German-language audiences to difference in the form of "other" cultural, racial, ethnic and linguistic voices. Sookee, however, sustains local political impact by rapping in German and furthermore utilizes her local "authority" in order to provide an interpretative framework through which her collaborators' work might be accessed and understood.

The changes Sookee wishes to effect in the hip-hop scene and among young people in Germany do not, however, progress unopposed. Apart from experiencing extreme pressure and opposition from within the hip-hop scene from the time she began performing in the early 2000s, she encounters criticism from within the leftist scene and from trolls online. The advantages of online media for artists working outside of the mainstream, as Sookee does — including self-publishing opportunities, increased visibility, circulation and networking opportunities — also sustain their disadvantages. A brief overview of Sookee's Twitter feed reveals a significant level of troll activity, usually in response to political and feminist tweets. This activity, alongside her desire to challenge representations and objectification of hypersexual femininity, may provide one reason for her decision to avoid placing prominent images of herself on her website. Sookee's usual strategy in the face of troll encounters is to answer with a link to the website Zero Trollerance ("Self-help for sexists in six simple steps”), but the conversations often 
continue when Sookee has left the conversation, making her the object of discussion. Sookee thematizes this in the piece "Zusammenhänge" [Connections], discussed above, when she raps: "Sexism sells, masculinity must be protected / women have kids, men get money and recognition / jokes whip through the internet if we just don't agree.”xvi (2013) In a statement made in Missy Magazine, Sookee points out that while the "thematic spectrum grows with the Zeitgeist of a medialized, globalized world", the internet becomes

our best friend and our worst enemy; mainstream media voices tend to trivialize urgent feminist issues; capitalism still knows no mercy and shoves the beauty industries, marketing strategies, job markets down our throats; and all the while patriarchal backlashes are rolled out uncontested and our reward includes conservative governments, a strengthening of rape culture alongside an increasing obsession with taboo-breaking sensations and unspeakable NS [National Socialist]comparisons as a reaction to feminist activism. ${ }^{\text {xvii }}$ (Sookee 2013)

Here Sookee highlights the ongoing challenges facing feminist activism both on and offline. This somewhat pessimistic portrayal of the contemporary "medialized, globalized" world stems from her analysis of the ways in which neoliberal and neoconservative forces avail themselves of the same mainstream media channels as feminist activists in order to further their own agendas. The internet is, for this reason, "our best friend and our worst enemy". As a result, Sookee contends that "just like contradictions within feminism, practical crises demand that priorities are set and that the space for the symbolic becomes capped" (2013). This statement reveals the tension inherent in Sookee's engagement with online media. The statement, itself available online, nevertheless questions the efficacy of online activism alone at times of intense social, political and economic crisis. Instead, Sookee here appears to call for prioritizing materially based action, of the kind she undertakes in her workshops, activism and creative work.

The critique she is exposed to within the leftist scene also requires her sustained attention. On the one hand, Sookee expresses gratitude on her website for the constructive criticism she receives from her peers. 
On the other, she speaks of the pressure she experiences to live up to the expectations of various interested and invested groups, partly because she is as yet one of only a few female artists doing what she does. Despite an acknowledgement that she keeps up-to-date with feminist and left-wing blogs and always looks out for new insights into language politics, Sookee claims she is "really not interested in living up to other people's expectations. We just need more politically motivated rappers* and that's that". xviii (2013)

The pivotal term "expectations" here foreshadows a later 2014 interview in which Sookee describes her audience's "expectations" as impossible to "live up to". These expectations entail that she has to "deal with being intensely celebrated and frequently shot down. Those are things that aren't visible, but they drain your energy". xix (Hakan 2014) After this interview was published, Sookee released a track on her most recent album called "Temporary Goodbye Letter" [Vorläufiger Abschiedsbrief ], which expresses her frustration and fatigue in the face of the conflicting tensions outlined above. She also expressed her intention to take a break from creative work for an unspecified amount of time.

This interview and the track are reminiscent of comments made by LBR/Reyhan Şahin in a 2012 interview. In the interview LBR discusses her recent hiatus in creative work and public appearances. Extreme exhaustion and poor mental health had led to her stepping back from public life. She discusses the point at which she realized that she "carried a certain responsibility" by virtue of continuing to "be" LBR. She claims that this sense of responsibility and the work that went with it put her under pressure to live up to her public's expectations and also prevented her from finishing her doctoral thesis. She goes on to suggest that the pressure she experienced — from fans as well as critics — stemmed from the complexity and provocative nature of her public persona: "It's easier to be in the media if you are a more straightforward person. If you're provocative, you're perceived as a trouble-maker. Apart from that, everything came together in one package with me: class, race, gender." ${ }^{\text {xx }}$ (Pohl 2008)

While I have pointed out the ways in which LBR and Sookee differ in terms of their aesthetics and political strategies, they do share a desire to provoke debate in order ultimately to provoke change. Sookee, rather than presenting an extreme parody of stereotypical, hypersexualized femininity, seeks to 
queer the hip-hop scene. As such she also constitutes a complex media persona, who, as I have shown, encounters critique from within the male-dominated hip-hop scene, the left-wing and queer subcultures in which she works and from those more anonymous voices navigating the world of social media. Based on comments from both LBR and Sookee and their shared decision to take a step back from public provocation, I suggest that one of the costs of blazing new political and creative trails is the risk of burnout and exhaustion.

Their shared decision to step back also functions perhaps as a reminder of the physical qua material dimension of subversive performativity. Like LBR, Sookee uses the visual as a performative speech act. To some extent, this is the work that her videos and media representations do. Yet Sookee's frank discussion of the very real weight of expectations and their material effects re-inserts the material dimension into the idea of performative images and free-floating texts circulating online. This of course echoes the thrust of her creative work as well as her pedagogical and political undertakings. In her creative work, Sookee's strategy is to foreground how language and the material world should not be understood as separate entities, but as coterminous phenomena. Identities become produced by discourse, and language produces bodies, and what concerns Sookee is "how power structures and identities become established in different social contexts and how these become incorporated and expressed". xxi

But the performance of identity remains a corporeal phenomenon: bodies produce and are produced by language. In the performance of raps and spoken-word poetry, Sookee demonstrates how the "body is neither brute nor passive but is interwoven with and constitutive of systems of meaning, signification, and representation" (Grosz 18). Her creative pieces constitute, in other words, "materialdiscursive" practices which enact the reconfiguration of political boundaries, and agency can emerge in the ongoing process of "reconfiguring" the world.

Digital versions of Sookee's work do not exist only in the abstract realm of representation and discourse - for as I have shown the discursive paradigm does not exist independently of the body. Sookee's website does not represent an idealized online utopia of queer feminist thought but functions 
practically, as a tool, and as a supplement to the important work of performance, youth outreach work and activism. The importance Sookee places on the political significance of lived experience, her performative persona and her understanding of language as profoundly connected to corporeality entail that the question of bodies inhabits her work whether on- or offline. Importantly, the body is not understood as a passive, predetermined surface but as a highly active and adaptable entity, open to change — and to extreme pressure and fatigue. The tension that this article has sought to explore between Sookee's use of digital media and her wariness of its more negative qualities lies therefore in an awareness that the online world all too often forgets its own materiality, that of other users and of those "represented" online.

Above all, though, it is the process of progressive political change, both discursive and material, that Sookee seeks to enact in her work and instigate in others, both locally and across wider cultural contexts. The progressive change that she is working for includes the transformation of the German hiphop scene from a male-dominated heteronormative arena which, in the mainstream, sustains homophobia and misogyny to one which provides a platform for a variety of other voices, identities and political perspectives. But it also includes working for change directly with the communities most affected by the misogyny and homophobia reproduced by rappers like Bushido and Sido: the young consumers of their products. By facilitating young people's critical engagement with rap lyrics, messages and the videos accompanying them, Sookee also works for progressive change in the tastes of the rap market by engaging directly with its consumers. The strategy of pursuing multiple transnational collaborations, both in the flesh and reproduced online, constitutes another way of realizing that change which complements Sookee's pedagogical and academic work. This tactic broadens the range of voices that share a home in hip-hop and queer feminism, specifically in the German context, but also — and precisely as a result of the digital traffic circulating their work - transnationally.

\footnotetext{
i The term "pro homo" is a subversion of "no homo", an expression which gained currency in New York (East Harlem) in the 1990s and soon spread to the hip-hop scene. As music journalist Jonah Weiner notes,
} 
the phrase is $[\ldots]$ "added to statements in order to rid them of possible homosexual double-entendre" (Weiner 2009).

${ }^{\text {ii }}$ Renowned German feminist Alice Schwarzer, for example, has spoken out on her website against the misogynistic lyrics of German rappers like, for example, Bushido and Sido.

iii "Wir haben keinen Bock auf das mackerige Gepose eines großen Teils der 'Hip Hop-Szene' und die homophobe und sexistische Sprache. Aber wir wollen mit der Doppelmoral von Politik und Medien gegenüber Hip Hop nichts zu tun haben. Stattdessen setzen wir eigene inhaltliche Akzente und suchen nach Gemeinsamkeiten und Bündnissen. Wir fühlen uns in der linken Subkultur zu Hause und wollen zum Soundtrack ihrer Bewegungen beitragen. Wir lieben den Austausch. Wir hassen die Apathie.” All translations from the German are my own.

iv See Peter Nowak. 2011. "Dein Block Mein Kiez: Gegen Ausgrenzung und Soziale Kontrolle". 17 June <http://deinblockmeinkiez.blogsport.de/> [Accessed 8 May 2015].

$\checkmark$ For a more detailed discussion of the "New German Girls" see Christina Scharff. 2012. Repudiating Feminism: Young Women in a Neoliberal World. Farnham: Ashgate; Emily Spiers. 2014. "Alpha-Mädchen sind wir alle' [We're All Alpha-Girls]: Subjectivity and Agency in Pop-Feminist Writing in the US, Britain and German", Doctoral Thesis. University of Oxford.

vi "MC Sookee will vom Feminismus à la Schwarzer nichts hören. Sie klagt darüber, auf 'die Frauenfrage' gebucht zu sein. Lieber will sie 'die Kategorie Geschlecht' überwinden, auch über Homophobie und Rassismus im Rap diskutieren. 'Third Wave Feminism' eben — statt der ewigen Geschlechterfrage 'Geschwisterlichkeit statt Schwesternschaft'. Applaus im Publikum, das klingt gut und neu."

${ }^{v i i}$ For a more comprehensive discussion of the blind-spots of neoliberal popfeminisms in Germany, see Emily Spiers. 2014. "The Long March through the Institutions: From Alice Schwarzer to Pop Feminism and the New German Girls," in Post-War Literature and Institutions. Special Issue of Oxford German Studies, 43:1, 69-88.

viii “Meine Aufgabe liegt mehr darin kommunikative Brücken zu shlagen und Präsenz zu zeigen. Also kümmere ich mich um queerfeministishen Aktivismus zwishen männerdominierten Subkulturen, autonomantifashistish bis links-parteipolitishen Kontexten und versuche einerseits, große bürgerlich-frauen*bewegte Bündnisse zu unterstützen als auch aktiv an den Diskursen radikalfeministisher Kämpfer*innen dranzubleiben."

ix Sookee began writing a PhD on language and gender in the GDR in 2009, but postponed her studies in order to devote more time to her creative and activist work. Her 2014 "Purple Velvet Tour" took Sookee with rappers Lex Lafoy (South Africa) and Shirlette Ammons (US) on a tour of Germany, Austria and Switzerland.

x "Quings Idee war Hip-Hop positiv zu irritieren / Was ist Queen? Was ist King? Ich hatte nix zu verlieren / Da war'n Leute, die meinten, ich bezöge mich auf zwei Geschlechter / Und ein drittes daraus zu bauen wäre auch nicht viel besser / Ich verstehe diesen Einwand, aber teile ihn nicht / Denn 'Quing' hat von Anfang an sehr viel weiter geblickt / Viel mehr stört mich die Line mit der Sexyness / Ich trennte den Kopf vom Körper, enthob letzteren / Wer bin ich zu entscheiden, dass Intellektualität / Begehrenswerter sei? Die Erkenntnis kam echt spät / Ist doch daneben Identitäten zu zerlegen / Es sei denn man wandelt derweil auf strategischen Wegen / Doch das entscheide nicht ich, das entscheidet jede für sich / Ich reich die Zeilen, ihr lest sie, beides fällt gleich ins Gewicht / Ich will nicht, dass man die Sätze zu 'nem Maßstab erhebt Ich stelle nur zur Diskussion, was ich tagtäglich erleb.”

xi "Bewegung in den Händen, Gesten, Moves und niemals Schluss / Meine Finger sind wie Stifte und ich schreibe in die Luft / Ich saug Silben aus der Atmosphäre, bau mir einen Sinn daraus / Ich ringe mit den Dingern und sie raten mir: 'Los, gib nicht auf!'”

xii "Und wenn ich ausweichen will, soll sie kleine Spitzen aus den Inhalten schnellen lassen, die / sich mit Widerhaken in meine Gedanken bohren, bis ich verstanden habe, woran ich denke, / woran ich schreibe." 
xiii "Sie sortieren abstoßend aufwändig ihre primäre Geshlechtsorgane und glotzen dabei garstig, / sie stellen sich in der UBahn zu dicht hinter eine und atmen eine an, / sie machen Sprüche und meinen diese bewusst provokativ, / sie machen Sprüche und meinen sie eigentlich als Kompliment, / sie können ihre Finger nicht bei sich behalten."

xiv "Basie" presumably refers to jazz musician and band leader Count Basie and his 1946 recording of the piece "Queer Street".

xv "Und alle paar Zeilen fragst Du dich: War das wirklich so? Oder habe ich mich grade in meinem Erleben verlesen? / Du bist für den Moment dein eigener Historienforscher, was dich autorisiert die /

Definitionsmacht an dich zu reißen. /Du bestimmst die Deutung deiner Denkweise."

xvi “Sexism sells, Männlichkeit darf nicht zu Schaden kommen / Frauen kriegen Kinder, Männer kriegen Geld und Anerkennung / Witze peitschen durch das Netz wenn wir darüber anders denken."

xvii “ [...] unser bester Freund und unser shlimmster Feind, Mainstream-mediale Stimmen tendieren zur Trivialisierung feministisher Notwendigkeiten, der Kapitalismus kennt immer noch kein Erbarmen und kotzt uns mit Shönheitsindustrien, Werbestrategien, Arbeitsmärkten voll, und ganz nebenbei rollen stabile patriarchale Backlashes die Allee hoch und runter und besheren uns konservative Regierungen, ein Erstarken von rape culture entlang von tabubrüchiger Sensationsgeilheit und unsägliche NS-Vergleiche als Reaktion auf feministishen Aktivismus."

xviii “Aber um das zu sagen: Ich halte mich immer auf dem Laufenden, lese viele, viele Blogs, schaue, was gerade thematisiert und diskutiert wird, um nicht hinter der Zeit zu sein. Ich schaue, was es für

sprachpolitische Erkenntnisse gibt. Aber trotzdem habe ich auch hier keine Lust, die Maßstäbe von anderen zu erfüllen. Es müssen einfach mehr politisch motivierte Rapper*innen her und gut ist."

xix “"[d]ie Leute haben auf jeden Fall eine Erwartungshaltung, der man nie gerecht werden kann. Ich muss mich damit arrangieren, extrem abgefeiert und extrem abgelehnt zu werden. Das sind Sachen, die nicht sichtbar sind, aber Energien ziehen."

xx "Es ist einfacher, als schlichte Person in den Medien zu sein. Wenn man provoziert, gilt man schnell als Störenfried. Bei mir hat sich außerdem auch alles vereint: Klasse, Rasse, Gender."

xxi “"[w]ie Machtstrukturen und Identitäten in verschiedenen Lebenszusammenhängen verfasst und wie diese geäußert und aufgenommen werden.”

\section{Bibliography}

Barad, K. 2003. "Posthumanist Performativity: Toward an Understanding of How Matter Comes to Matter"

Signs 28 (3): 801-831. http://www.jstor.org/stable/10.1086/345321.

Bhabha, H. 1994. The Location of Culture. London: Routledge

Boler, M. 2007. "Hypes, Hopes and Actualities: New Digital Cartesianism and Bodies in Cyberspace” New Media \& Society 9 (1): 139-168.

Braidotti, R. 1996. "Cyberfeminism with a Difference” New Formations 29: 9-25.

Brophy, J. E. 2010. "Developing a Corporeal Cyberfeminism: Beyond Cyberutopia” New Media \& Society 12 (6): 929-945.

Butler, J. 1990. Gender Trouble: Feminism and the Subversion of Identity. New York: Routledge 
Davis, T. 2010. “Third Spaces or Heterotopias? Recreating and Negotiating Migrant Identity Using Online Spaces” Sociology 44 (4): 661-677

Foucault, M. 1986 [1967]. “Of Other Spaces: Utopias and Heterotopias”. Translated by Jay Miskowiec Diacritics 16 (1): 22-27.

Gräbner, C. 2011. “"The Hurricane Doesn't Roar in Pentameters': Rhythmanalysis in Performed Poetry” Thamyris/Intersecting: Place, Sex and Race, Performing Poetry: Body, Place and Rhythm in the Poetry Performance. Editors Cornelia Gräbner Arturo Casas 24: 71-88

Gräbner, C. and Casas, A. 2011. "Introduction” Thamyris/Intersecting: Place, Sex and Race, Performing Poetry: Body, Place and Rhythm in the Poetry Performance 24: 9-20.

Grosz, E. 1994. Volatile Bodies: Toward a Corporeal Feminism. Bloomington: Indiana University Press. Hakan. 2014. "Entweder volles Herz oder gar nicht" — Interview mit Sookee. 14 April <http://kleinerdrei.org/2014/04/entweder-volles-herz-oder-gar-nicht-interview-mit-sookee/>.

Hutcheon, L. 1988. A Poetics of Postmodernism. History, Theory, Fiction. New York: Routledge.

Imre, A. 2009. Identity Games: Globalization and the Transformation of Media Cultures in the New Europe. Cambridge, MA: MIT Press.

Kemp, S. and Squires, J. (eds.) 1997. Feminisms. Oxford and New York: Oxford University Press. Mueller, A. C. (ed.) 2004. German Pop Culture: How "American” is it? Ann Arbor: University of Michigan Press.

Paterson, N. 1998. “Cyberfeminism”〈http://www.vacuumwoman.com/CyberFeminism/cf.txt〉

Plant, S. 1998. Zeros and Ones: Digital Women and the New Technoculture. London:

Fourth Estate.

Pohl, I. and E. Ippolito. 2008. "Ich bin ein moralischer Mensch”, Interview mit Lady Bitch Ray. taz.de 〈http://www.taz.de/1/archiv/digitaz/artikel/?ressort=ku\&dig=2012\%2F01\%2F28\%2Fa0031> [Accessed 12 January 2015]. 
Sookee. 2011a. "bitches butches dykes \& divas” Bitches Butches Dykes \& Divas (Springstoff)

2011b. “D.R.A.G” Bitches Butches Dykes \& Divas (Springstoff)

2011c. “Lernprozess 2” Bitches Butches Dykes \& Divas (Springstoff)

2011d. "Mach was!” published on website http://www.sookee.de/material/lesen/spoken-word/

2013e. “One Billion Rising” (Springstoff)

2010f. "Pro Homo" Quing (Springstoff)

2011g. "purpleize hiphop” Bitches Butches Dykes \& Divas (Springstoff)

2010h. "Rückspiegel” Quing (Springstoff)

2013i. “Sookee: Statement der Rapperin und HipHop-Aktivistin zu fünf Jahren Queer-Feminismus”. Missy Magazine. 10 November <http://missy-magazine.de/2013/11/10/sookee/> [Accessed 1 May 2015]

2011j. "Wordnerd” Bitches Butches Dykes \& Divas (Springstoff)

2010k. "Wortgewaltverherrlichung” Quing (Springstoff)

20131. “Zusammenhänge/Spuck auf rechts \#12” (Springstoff)

Spender, D. 1995. Nattering on the Net: Women, Power and Cyberspace. North

Melbourne: Spinifex Press.

Stehle, M. 2012. "Ghettos, Hoods, Blocks: The Sounds of German Space in Rap and Hip-Hop”, in Germany in the Loud Twentieth Century. Editors F. Feiereisen and A. Merley Hill. Oxford Scholarship Online. DOI: 10.1093/acprof:oso/9780199759392.001.0001.

— , 2012. “Pop, Porn, and Rebellious Speech” Feminist Media Studies

12:2: $229-47$.

Sunden, J. 2001. "What Happened to Difference in Cyberspace? The (Re)turn of the She-cyborg" Feminist Media Studies 1 (2): 215-32.

Terkourafi, M., 2010. The Languages of Global Hip Hop. London: Continuum.

Ticktickboom: Info. Website < http://www.ticktickboomcrew.de/info/> [Accessed 13 April 2015]. 
van Zoonen, L. 2002. “Gendering the Internet: Claims, Controversies and Cultures” European Journal of Communication 17 (1): 5-23.

Weiner, J. 2009. "Does This Purple Mink Make Me Look Gay? The Rise of No Homo and the Changing Face of Hip-Hop Homophobia.” The Slate, August 6 <http://www.slate.com/articles/arts/music_box/2009/08/does_this_purple_mink_make_me_look_gay .html> .

Wild, L. 2008. "HipHop-Debatte mit Alice Schwarzer: Leerstelle zwischen Heiligen und Huren” Spiegel-Online. 10 August <http://www.spiegel.de/kultur/musik/hiphop-debatte-mit-alice-schwarzer-leerstelle-zwischen-heiligenund-huren-a-571100.html> [Accessed 10 March 2015].

Emily Spiers is Research Associate at Lancaster University and Lecturer in German at Wadham College, Oxford. Her doctoral thesis explored questions of subjectivity and agency in pop-feminist writing in the US, Britain, and Germany. Her post-doctoral research project examines contemporary spoken-word poetry in Anglophone and German contexts through a feminist lens.

e.spiers@lancaster.ac.uk 